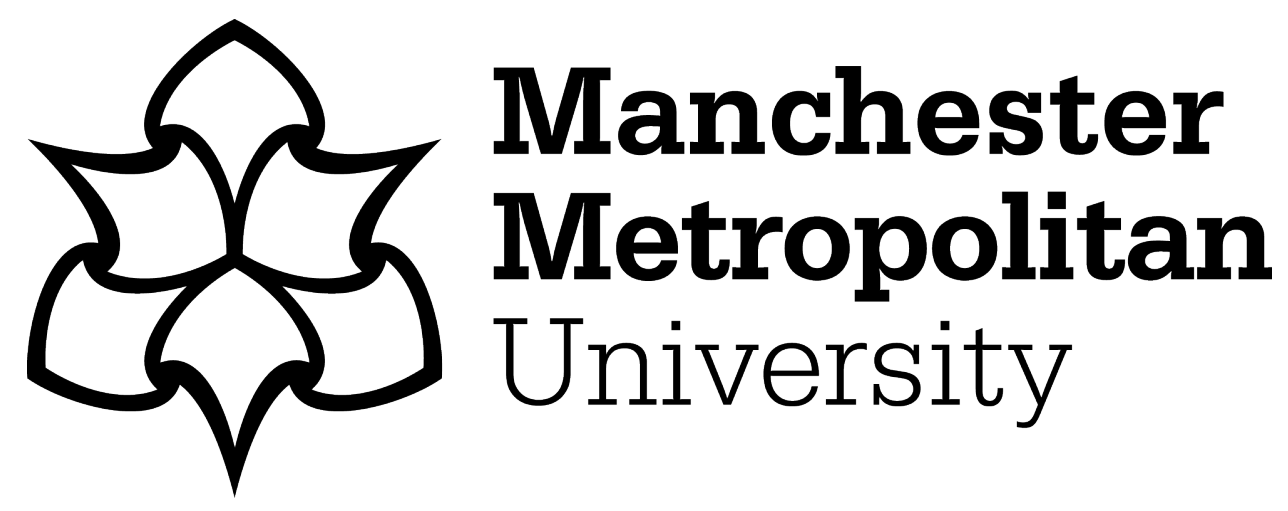

Trafi-Prats, Laura (2019) The Cucumber Party: For a posthumanist ethics of care in parenting. In: Ethics and research with young children. Bloomsbury. ISBN 9781350076433

Downloaded from: https://e-space.mmu.ac.uk/623419/

Version: Accepted Version

Publisher: Bloomsbury

Please cite the published version 


\title{
The cucumber party: For a posthumanist ethics of care in parenting
}

\author{
Laura Trafi-Prats
}

Manchester Metropolitan University, UK

\begin{abstract}
:
Through a feminist science and technology studies lens and a microethnographic perspective, this chapter examines parenting as a speculative experiment in living, a more than human to human relation that is situated alongside the animal. It mobilises a posthuman ethics of care in which parents and children learn to know partially, sensuously and intensively how to care with/for others, and beyond the normative frames of neoliberal governance. Through anecdotes involving walking in the neighbourhood, being alongside snails, making, looking at and talking about pictures created with mobile phones and GoPro cameras, care in parenting is discussed as a dynamic of attachment and partiality that carries material consequences in the making of worlds.
\end{abstract}

Keywords: Ethics of care, posthumanism, parenting, video-research, early childhood 


\section{The cucumber party: For a posthumanist ethics of care in parenting}

\section{Introduction}

This chapter considers relations between parenting, care and the everyday through a posthumanist ethics of care, which thinks parenting as being situated in concrete matters involved in the maintenance of forms of life that are messy, carry tensions and raise questions (Puig de la Bellacasa, 2017). A posthumanist ethics of care seeks to undo the individualisation and normativisation of care in which care is seen as a moral obligation that can be rightly done. Puig de la Bellacasa (2017) affirms that care is "everything we do to maintain, continue and repair our world so we can live in it as well as possible" (p. 3). A posthumanist ethics of care conceives this as well as possible as a "speculative opening about what a possible involves" (Puig de la Bellacasa, 2017, p. 6). Care is thought as a problematic where the question of how to care is not resolved with a set of idealised meanings but encountered as a situated provocation. A posthumanist ethics moves care towards a critical ontology in the sense formulated by Foucault (1984), as a philosophical ethos that not only examines the limits of anthropocentric ethics where care is something that only humans do, but develops "experiment[s] with the possibility of going beyond them" (p. 50).

I want to stop for a moment on this concept of critical ontology (Foucault 1984) to note the work done so far by the emerging field of parenting studies. I want to examine how this work relates to the two parts of this ontology, which are: historical analysis and speculative experimentation. In the U.K., parenting studies constitutes a small field situated in the intersection of social theory, policy analysis, and childhood and family studies. It emerges and articulates in the context of an increased individualisation of social life. This individualisation goes back to cutbacks to the welfare state that began in the Thatcher years and continued through the governments that followed (Jensen, 2018). In this respect, 
parenting studies methods have relied on the critique of hegemony and the analysis of neoliberalism as a historically formed discourse in which the family is considered the central unit over which the governance of the State is deployed (Jensen, 2018). Parenting studies have dedicated efforts to criticize the politics (McRobbie, 2013), policies (Clarke, 2006; Burman, 2007; Jensen, 2018) and public discourse (Rose, 2018) that repeatedly deliver a paradoxical understanding of the family, both as a resource and a danger for social renewal.

Going back to the argument that a critical ontology involves considering care not only as a project of historical analysis but one that involves experimentation, I note that parenting studies still lacks a theorisation of parenting as an experiment in living. This is, a thinkingdoing of parenting as a speculative exercise that can offer a glimpse of what life in the care of/with others might be beyond the excruciating limits of neoliberal governance (also see Rousell \& Cutter-McKenzie, 2018). With the intent to experiment with parenting, I mess with one of its limits: the assumption that parenting is a human to human relation that centers on becoming human. My questions are: what else can be thought and done in parenting by the troubling of the human and animal binary through the lens of feminist science and technology studies and a posthumanist ethics of care? Will this troubling allow for both an examination but also an experimentation with different orders of relations? (Foucault, 1984).

In the sections that follow I review but also experiment with different orders of relations between care, parenting, the everyday, the animal and image technologies. In the first order of relations, I look into the human/animal binary operating in the discourse of human exceptionalism, and how it renders some instances of humanity, for example mothers and children, close to the animal. I connect this to an examination of parenting policy exposing how the human/animal binary is active in the ways vulnerable parents living in poverty in the U.K. are both targeted and othered as less than human. Second, I turn to microethnographic work that I do as mother with my daughter Ingrid and my partner Eric 
(see also Trafi-Prats, 2018, 2019) to experiment with other possible orders of relations that conceive parenting as a lived and situated practice that perhaps could be imagined alongside the animal. Latimer (2013) describes the notion of being alongside animals as a way of experimenting with other concrete and collective ways of being-with "that can throw us into a world beyond ourselves" (p. 79). In the final section of the article, I continue thinking with this concept of being alongside other kinds by examining the role of video and photo technologies in intensifying our awareness of how we (Ingrid, Eric and Laura) cared vitally and in situated ways, through doings and undoings, attachments and detachments with other kinds that eventually made and remade the worlds we dwelled in/with more-than-human others.

\section{The animalisation of parenting}

Human exceptionalism, defines the human as separated from worldly matters. In human exceptionalism, reason, consciousness and morality are considered key human attributes, which are asymmetrically situated against the realm of the physical (Frost, 2016). Body, animals but also women (mothers) and children are constituted as knowable and available to mastery. By being associated to the physical world animals are seen as resources for knowledge, work, and food. Animals are only perceived as valuable for what they do and afford (Latimer, 2013). As Grosz (2011) has pointed out, identical mechanisms to those of othering the animal appear in certain discourses around femininity strongly associated to the body and nature. Also, Burman (2007) has described how developmental psychology was forged by a confluence of practices stemming from biology, ethology, anthropology and the medical sciences which constituted the child as an object of study. In this order of relations, the animal is at the center stage of a process of othering where multiple others are rendered as less than human, objectified and situated closer to the animal. As Latimer (2013) affirms, "the asymmetrical power relations between the human and the animal means that humans 
themselves can be figured as too animal; that is, as insufficiently cultivated or not civilized enough" (p. 85).

I want to consider the power of the human/animal binary in shaping contemporary parenting policy. In the U.K. the policy discourse around parenting follows the global trend of associating parenting to social opportunity, the reduction of inequality, and economic growth via the ability to work and compete in the global market. Parenting behaviour and life style have become a matter of public concern that permits government intervention in what could otherwise be considered an invasion to the fundamental right of privacy (Dermott $\&$ Pomati, 2015). Very specific techniques such as looking directly at the child when you speak, reading to your child, supporting her homework, attending school parent evenings are featured in government reports, but also on popular parenting websites, as measures of good parenting directly associated to academic outcomes and future success in life (Field, 2010).

In the second decade of the 2000 s, the increase of the inequality and poverty provoked by the financial crisis was followed with a move towards an individualised explanation of poverty (Dermott \& Pomati, 2015), and a more intense targeting of underprivileged families who were often portrayed as the cause of social conflicts (Jensen, 2018). In 2010, the Field Report offers a strategy to address childhood poverty through good parenting roles. The concept of good parenting is based on the disassociation between material conditions and techniques of so-called good parenting (Dermott \& Pomati, 2016). Field (2010) writes, "Something more fundamental than the scarcity of money is adversely dominating the lives of these children" (p. 17). This separation of wealth, class, ethnicity, health from practices of parenting continues at the center of later policies of early intervention (Allen, 2011) and workless families (DWP, 2017). The language of these policies is of an intense negativization with a vocabulary that is othering and vile, and that renders parents living in difficulty as national burdens, and solely responsible for making their life conditions challenge the 
chances of their own children. Everything in these policies aligns with the discourse of human exceptionalism: the treatment of families and children as disposable resources, the disdain for the material life conditions of parents and the belief that parenting is a mental state that could be practiced regardless of situated experiences, as well as the reduction of good parenting to specific logocentric practices around language, rationality, and human to human interaction.

\section{The re-materialisation of parenting through attention to care}

In critical opposition to human exceptionalism, feminist science technology studies (from here on FSTS) articulates around a relational ontology in which the question of how connections are made and how connections matter is put at the center. Haraway (2016) writes, "It matters what thoughts think thoughts. It matters what knowledges know knowledges. It matters what relations relate relations. It matters what worlds world worlds. It matters what stories tell stories" (p. 35). FSTS consider knowledge-practices not as a source that provides reality, but as multiple situated practices embedded in concrete worlds, and how these practices carry consequences by contributing to the sustenance or decay of these worlds. The concept of care is central to FSTS, not as a normative framework such as quality care or good parenting, but as a speculative question of how to care for worlds made of more-than-human assemblages of bodies, technologies, things, places, affects. This is, how to care for worlds that keep life going in a damaged and impoverished planet, where concrete, mundane but critical practices of care have little recognition and provoke considerable struggle (Puig de la Bellacasa, 2017). Differently, from the parenting policies discussed earlier, this posthumanist ethics of care focuses on situated knowledges:

[It] cherishes insight for alternative relatings to be found in the worlds of the domestic, petty ordinariness, the difficult and playful, the joyful and aching 
mediations of caring affection, crucially involved in everyday experiences of interspecies intimacies in contemporary natureculture worlds. (Puig de la Bellacasa, 2017, p. 88)

Puig de la Bellacasa (2017) more than proposing a universal idea of care that applies to all situations, affirms care's partiality. Taking part is needed in care to "Think from and for particular struggles, [which] require from us to work for change from where we are, rather than drawing upon other's situations for building theory, and continue our conversations" (p. 87). Puig de la Bellacasa's ethics of care offers important provocations to re-align parenting with care as a way to return materiality and situatedness to cultural understandings of parenting. But also, to see parenting in worlds of relations that are more than human to human as a way to practice the critical ontology discussed earlier (Foucault, 1984), which requires possible experiments of going beyond the assumed limits of how to care. These could be worlds of relations that enable parenting to be positively articulated through embodiment, affect, curiosity and the multiplicity of unconnected and random experiences involving being a mother that resist cohesivity and grand narratives of parenting but that still speak of care-doings and care-knowings (Baraister, 2009).

\section{A situated story of care in parenting}

Bodies of/in care are done in mundane everyday practices. Considering this, Lisa Baraister (2009) defends an anecdotal approach to parenting, that foregrounds the raw materiality of parenting (sensations, intensities, moods, encounters) where something extra is issued provoking an ethical movement towards difference, "between what it is and what is ought to be" (p. 152) between "pleasure and obligation" (p. 152). Paying attention to the materiality of my everyday world, I cannot think in it as just made of human to human relations. I don't have a car, so I walk to many places. Often Ingrid, my daughter, walks alongside. In our 
walks we encounter, observe, and become committed to urban animal species with which we share and compose territories over iterative and prolonged time periods of being alongside.

Latimer (2013) affirms that being alongside animals is ethically and politically relevant because it permits imagining and practicing other forms of sociality based on being-with other kinds "that helps us escape the worst consequences of human exceptionalism and its ordering of relations" (p. 93). Latimer (2013) differentiates her notion of being alongside from Haraway's (2003) notion of companion species that completely eradicates the prior figures of human and animal and focuses exclusively on patterns of interspecies relationality. As Latimer (2013) affirms, Haraway "goes beyond the individual and the divide" (p. 92) and in doing so her theory is more about hybridity than thinking in terms of "partial connections alongside partial division" (p. 93).

Being alongside is a concept that argues against the idea of blurring differences between human and animal. While Latimer values the radical onto-epistemological affordances mobilised by Haraway's concept of companion species, she nevertheless considers key to think with the tensions, and "the irreducibility of parts that can never settle into a whole" (Latimer, 2013, p. 93) in human and animal relations. Being alongside other kinds seems close to a posthumanist ethics of care that enacts both attachment and detachment, connection and division while avoids producing a comparison human-animal. I explore this idea of connection in partiality a bit further through an anecdote featuring Ingrid, Eric, I, multiple snails, a rat, walks and the backyard of the apartment building where we currently live.

Our first Spring in England was characterised by long days deploying a mix of periods of rain and sunshine. In our walks to the school, Tesco or the park Ingrid and I were enchanted by encountering numerous snails traversing the narrow sidewalks in Monton 
Road. We would look at their slime tracks, their slow movements through impossible surfaces, their striking shells and sensing antennae. But we would also see many of them crashed by feet and vehicles. We soon felt affected by the repeated slaughtering of snails that we saw day after day of rain and sun. "Mama, Google why they don't know that they are going to die if they walk in the street" I Googled this topic and we learnt about the unsophisticated nervous system of the snail and how it cannot communicate danger to other snails. Ingrid soon began a practice of picking up the snails from the middle of the street and situating them back in nearby bushes. We continue today doing this practice if the suctioning/attaching powers of the snail allow us. Also, back in Spring of 2016, Ingrid discovered that a number of bushes in our apartment building in their shady areas hosted numerous sleeping snails. We began spending time visiting and perusing the bushes some evenings after school. Ingrid would carry a spray bottle and would try to wake up the snails, hold them in her hand and observe them moving. She also initiated a collection of empty snail shells that she encountered in her walks. One of the shells that she picked up during an excursion to a nearby forest by the Liverpool coast was not empty at all. As it was drying over a kitchen towel we noticed that a hole appeared in the paper and that a snail was eating it. Ingrid was ecstatic and wanted to keep the snail, now named Banana, in the house. Eric and I convinced Ingrid that Banana would be better off living outside and that we could do a cucumber party and help Banana meet some of the snails in the bushes. From this followed that for a number of evenings Ingrid would be cutting slices of cucumber, going downstairs and hosting cucumber parties for/with snails, Eric or I would go alongside. One of the mornings that Ingrid and Eric went down to clean the cucumber remains, they found a dead rat with a hole near the head and pellets around. Ingrid invited me to go down and see it, but I couldn't follow this time. Eric collected the rat with a plastic bag and 
deposited it in the garbage. I was horrified, not only for the rat but because the cucumber snail parties may have attracted the rat, and also attracted the person that lived in our building who shot the rat. "Mama, Google if rats eat snails." Effectively they do. There is even a blog that explains that one sign that points to the existence of rodents is finding around your building empty and perfectly clean snail shells. The cucumber parties got cancelled. That same morning, I washed again the collections of snail shells contained in our house and the boxes and surfaces where they sat.

I think that this anecdote illuminates well Puig de la Bellacasa's (2017) idea about the situatedness of care. Being in zones of contact where people, snails, rats, garbage, and, and, and live alongside, provoked us (Ingrid, Eric, and Laura) to think of worlds that are ongoing, done and undone and made of an excess of bio-historico-cultural layers. Such zones of contact emphasize the lure of closeness and touch, but also the awareness of alterity marked by the unexpected of being alongside with other kinds. While these worlds may not always feel "pleasant or liveable, they have something situated to teach us about caring proximities" (p.116).

Care is always partial. Ingrid, Eric and I could care for the snails in some ways, like not stepping on them and being sensitive and complementary to the powers of their nervous system. However, we failed to care in other ways. By organizing cucumber parties we left them exposed to their predators. Eventually, we stopped caring so intensively, especially when we understood that snails and us were interdependent with rodents, and that rodents and other humans who hate rodents could be a threat to our livelihood. In care we became affected and responsive to some matters and not others.

Care, writes Puig de la Bellacasa (2017), needs "reciprocal exposure and vulnerability, rather than speeded efficacy or appropriation" (p. 116). Efficacy and appropriation are 
precisely at the center of good parenting and the assumption that there are a number of universal practices that can be abstracted from context and appropriated by all parents, and that such practices will correlate with educational success (Dermott \& Pomati, 2018). As Hackett (2017) has discussed, these correlations are often presented with a positivist rhetoric that feels scientific, and right. Their effects in pathologizing the lives of poor families are profound (see also Burman 2007).

Using the language of Clarke and Haraway (2018) in Making Kin not Population, possibly, a posthumanist ethics of care propels an understanding of parenting that is less a project towards the economization of populations in need of governance, (e.g. parents living in poverty) that objectifies and dehumanizes, and is more a project of making kin across multiple and various worlds. Makin kin connects species and environmental reproductive justice by affirming that forced models of child development are not disconnected from other models of forced development that concern the environment such as plantation regimes, mono-cropping, industrial animal generation and their lethal consequences including species extinction, loss of refuge, deforestation, genocides, and pathologization of the poor, to name some (Haraway, 2018). Clarke (2018), describes making kin as "daily actions that transform partial relations into deeper ones, kinship crafted through the exchange of things, sharing activities, and other practices" (p. 33). Thus, making kin with snails reintegrates affectivity, bodily attachments, material creativity and passionate observation, in a form of knowing as care that avoids abstraction and distance. In this onto-epistemology, attending to care seems to be in the opposite pole of good parenting understood as a universal protocol of practices. As Puig de la Bellacasa (2017) affirms, it is by delving into the materiality, partiality and embeddedness of care that we can become more ethically aware about its material consequences. 


\section{Intensifying ethics of care with photo and video matterings}

I want to take a step further in grappling with the materiality and partiality of care-knowings in parenting by suggesting that issues and dilemmas of care can be intensified by technology and uses of technology that problematize both vision and what is to be in closeness with other kinds (Puig de la Bellacasa, 2017). It has been central to FSTS to recognize the agency of artefacts and the mediation of technology in the production of knowledge and worlds (e.g. Haraway, 1997; Barad, 2007). FSTS have actively questioned the anthropocentric, colonial, and positivist understanding of technology as a form of human enhancement and human progress. They have defended an ethical approach that connects specific uses of technology to its matterings and consequences towards other human groups, species, ecologies, and planet (Haraway, 2016). At the same time, FSTS have been generative in thinking radically and playfully with technology, and have argued for feminist ways of composing technology with bodies, places and philosophical concepts that propel experimentation with alternative ways of living (Braidotti, 2013). Following this legacy, Puig de la Bellacasa (2017) affirms the need to make everyday technologies a matter of care, not of enhancement, by thinking in the consequential and situated matterings as well as overlooked possibilities of specific technological compositions. I want to consider this framework of ideas in order to think about how a phone camera was generative of care-knowings connected to our (Ingrid, Eric and Laura's) walks and encounters with snails in the neighbourhood.

I (Laura) often participated in the encounters with snails via practices of looking, talking, approaching, sensing through the lens of my phone camera. I have copious pictures of things that attracted my attention when being alongside snails. Figures 1 contains 4 photographs that reflect a small representation of this collection. Figure 1's top left photograph depicts a snail moving in the middle of the street close to Ingrid's toes. It is an image captured after repeated experiences of finding snails detoured in the sidewalk after a 
short rain. In this case, I felt attracted to the fleshiness of Ingrid's skin in strange co-presence with the snail, both abstracted from the surroundings. Figure 1's top right photograph is a close-up of a snail that Ingrid detached from the concrete as it retreated inside its shell. Again, it is a picture of what became a common gesture during our walks after learning that snails couldn't sense or anticipate danger. Figure 1's bottom left photograph is a of a cucumber slice and snails with what Ingrid described as “a loopy shaped snail poop”. Ingrid quietly observed the animal defecating and appreciated the shape of its excrement. Figure 1's bottom right photograph relates to the moment when Ingrid brought Banana to his first cucumber party and expected that Banana would instantly set direction towards the fresh cucumber slices. The acts of making these photos were situated in an ecology of sustained relational action between Ingrid, Eric, I, the snails, and the neighbourhood. Although the pictures were authored with the orientations and gestures of my (Laura's) body, aesthetic choices and the technical affordances of the phone camera, the act of making them brought group responses and connectedness. Ingrid and Eric often stopped with me and looked at what I was picturing. Sometimes this initiated a conversation about it, or provoked further related actions. Making pictures made us notice things in the snails and the neighbourhood that otherwise we would not had paid attention. In doing all this we (Ingrid, Eric, and I) progressively built an interest and knowledge on the snails and attuned towards their movements, and presence. 

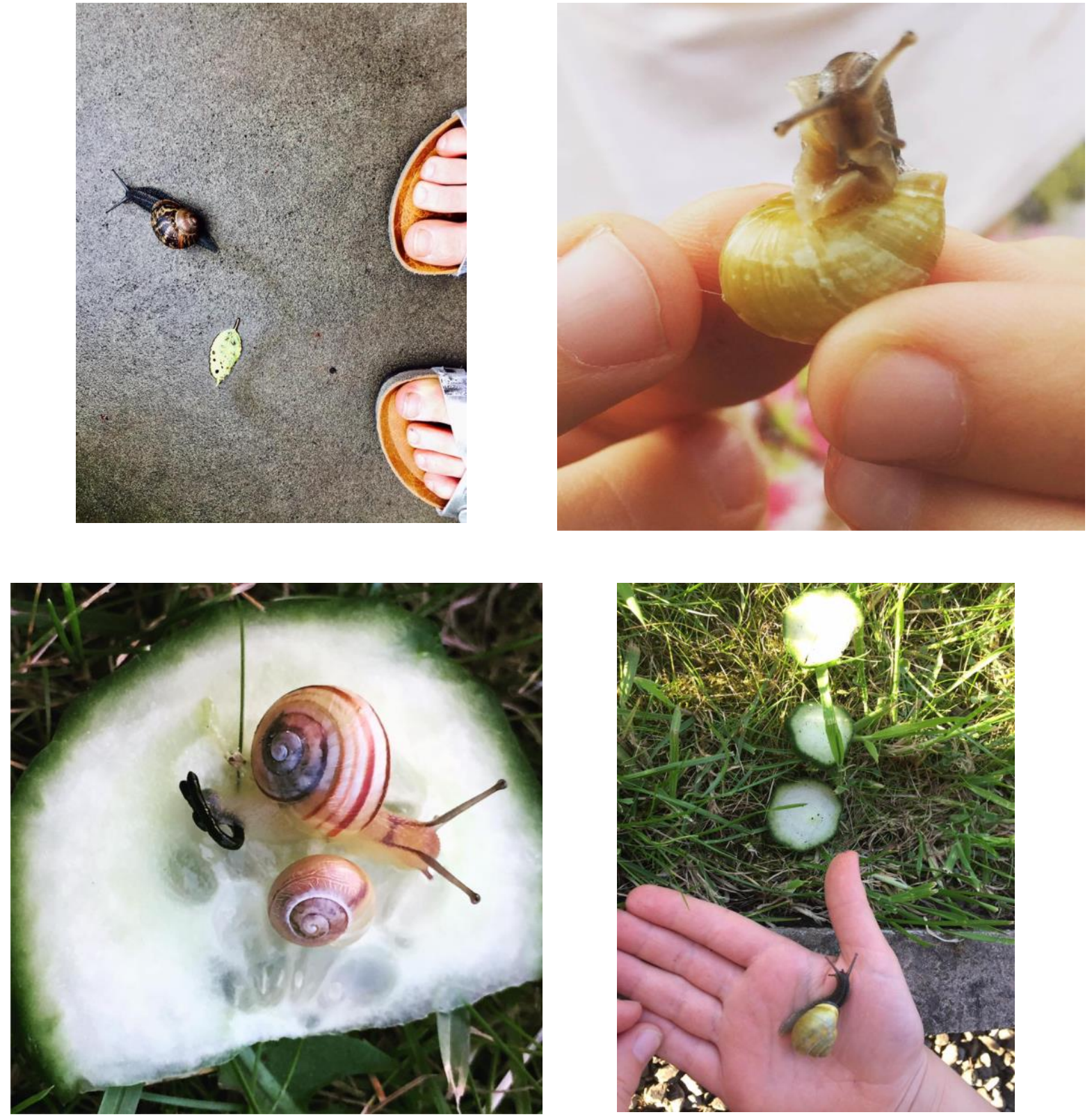

Figure 1. Composition of four individual photographs showing different encounters and interactions with the snails, Summer 2017. Photographs by Laura Trafí-Prats with iPhone camera app.

Looking back at the pictures on our digital devices at home made us aware that the lure of being close and in contact with the snails combined with an increased awareness of their 
alterity (Puig de la Bellacasa, 2017). Looking and casually talking about the images unintendedly implicated us (Ingrid, Eric and I) in the ontology of being alongside other kinds (Latimer 2013), and its partial knowing made of connections and disconnections. For instance, in a conversation that Ingrid and I had around Figure 1's top right photograph, Ingrid enacted a sense of connection with the snail by noting the tenderness of her hands holding the snail quite carefully. She explained that different from other snails who had retreated quite quickly inside the shell after being picked up, this one was especially unique because it lingered on. She valued how as a result of this, we could see its body in movement, partially contracting. Additionally, Ingrid pointed at a sense of disconnection by noticing how her body marginally fitted in the frame. This disconnection intensified when Ingrid asked me why I had not captured her face, which she remembered being quite close to the snail. This made her appreciate that in the picture the snail eyes were facing away. This informal conversation seems to reveal that Ingrid intuitively felt that the image performed both a sense of connection and disconnection between human and animal. At the same time, the perception and recollection of the event did not produce a comparison human-animal where Ingrid emerged as sovereign but enacted a moment of mutuality in difference (Latimer, 2013), which the making, looking and conversing with the aforementioned picture intensified. Cinema scholar Laura Marks (2002) argues that close up bodied images, like Figure 1, generate a desire for closeness. It is in the specificity of this closeness that we (Ingrid and I) could recognise the unknowability of the other and the impossibility of knowing wholly. What is ethical in the practice of making-viewing images that mobilize both connection and unknowability is that such unknowability brings the possibility to stretch perception towards what resists being seen, sensed and represented. Parenting with a posthumanist ethics of care needs of experimental practices of "inhabiting the potentials of neglected perception, of speculative commitments that are about relating with, and partaking 
in, worlds struggling to make their other visions not so much visible but possible" (Puig de la Bellacasa, 2017, p. 118).

I want to stop on this idea that image-making could help us develop speculative and experimental commitments to worlds. I do this by considering Ingrid's growing interest and practices with a chest-mounted GoPro camera. In the context of the snail anecdotes, Ingrid wore this GoPro during the cucumber party when we (Ingrid, Eric and Laura) returned Banana to the outside. At that point, Ingrid had already experimented wearing the GoPro on other walks and around the house, and enjoyed the wide-angle lens: how it rendered unusual perspectives of her long hair propelled by the movements of her body, her arms and hands moving or holding something from the inside, and the exaggerated length of her legs when viewed from above. In an ethnography concerning the use of GoPro cameras in a primary school computer club, Caton and Hackett (2019) have described children's behaviour with the chest-mounted cameras as one that dislodges the axis of perception from the height of adult eyes to the varying heights of children's chests, forcing a less adult-centric intimacy with the world. A world that is seen from a different perspective that raises aesthetic connection with environments and objects through novel and unexpected views.

Certainly, the video generated by the chest-mounted GoPro produced a different perspective from the ones embodied in Figures 1, 2, 3, and 4 made with a hand-held phone camera and Laura's point of view. As Elwick (2015) suggests, we may perceive and sense an event differently when seen from two different cameras, used in different ways and by different bodies. Elwick's (2015) proposition of perceiving an event from different perspectives contributes to the idea of a speculative stretching of perception argued above. It de-naturalizes the adult's gaze that populates narratives of care and education, where images are used to speak about children's worlds objectively without questioning their mediating and materializing forces (Kind, 2013). It brings an ethical orientation in which Ingrid, Eric and I 
have felt propelled to see images as relational fields where it is possible to feel connectedness while at the same time discuss the tensions and bifurcations that our different perspectives and perceptive modes enact (Puig de la Bellacasa, 2017).
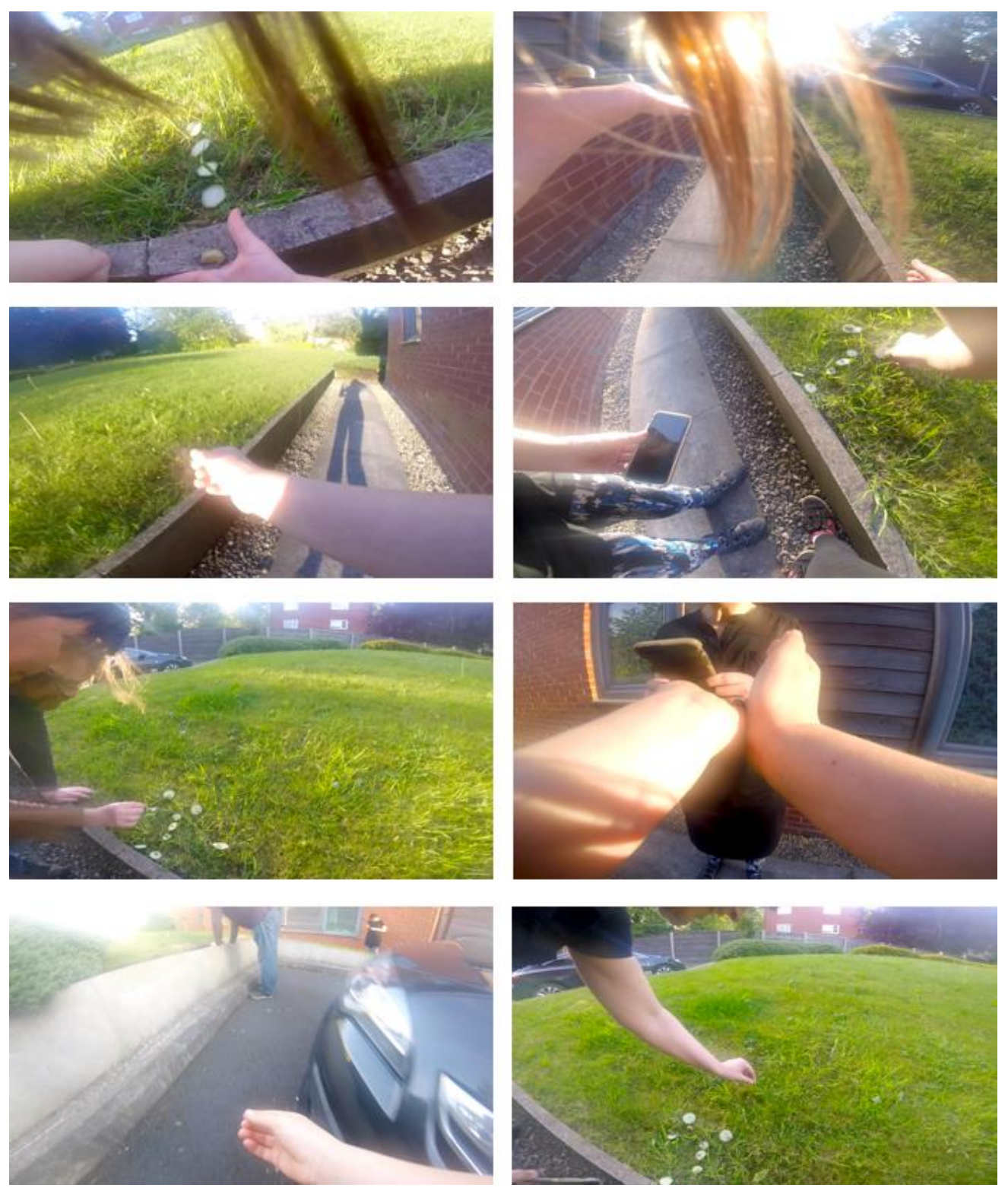

Figure 2. Selection of video-stills from the first cucumber party, Summer 2017. Video by Ingrid Caudill-Trafí with chest-mounted GoPro Hero 5. Manipulated and reproduced with kind permission of the videographer.

Figure 2 showcases different frames extracted from video footage of the first cucumber party, where Ingrid wore the chest-mounted GoPro. Multiple bifurcations can be perceived in 
these images. There is an ongoing contrast between human bodies and how these bodies act around the cucumber party. I (Laura) am holding my phone camera in active practices of looking through and outside of it, while tending my arms sometimes towards the snails, other times towards Ingrid, but I am never too far from the cucumber site. Ingrid's body, the peripheral parts that we can see through the GoPro (arms, legs, feet, hair), moves vividly along the perimeter of the building, and occasionally returning to the cucumber site. She walks, runs, stops to observe, picks, walks, deposits. While moving, she projects long shadows, blocks and unblocks the low sunlight at dusk. The video captures the modifications of light, atmosphere and space that Ingrid's movement materializes.

The GoPro images also deploy striking differences in scale, awkward framings, and the deformed optics which render the snails marginally visible, when in principle they were the motive of all this activity. The video emerges as a diagram of the embodied, fragmented and de-centered gestures and actions (bodies walking, bodies standing, fingers holding, arms tending, torsos bending, eyes looking, phones capturing) and the movement (lines, forces, energies) that materialize the technologically mediated vision of environmental relational activity. A diagram is not a figure that represents or tells but one that maps fluctuating and incorporeal processes happening between bodies and static structures as pure abstract forces in a coextensive ongoing field (Zdebik, 2013). Perceiving this video diagrammatically permits to think it as more than a capture and closer to a complication where what is visible can only be articulable as expressive ways of collective being, occupying, making and remaking the territory of the cucumber party. This productivity cannot be abstracted to form a cohesive sign. In this respect, the video-footage as a diagram links to the mundane and to an ethics of care where vision does not correspond anymore to a humanist metaphor linked to clarity and unmediated access to a distinct world. As Puig de la Bellacasa (2017) argues, this is another way of thinking vision, where the experience of seeing touches us. More 
specifically, she calls it a touching-vision, or a vision that is moving and felt in the body. What moves us, makes our body act, is to understand that our ways of seeing and knowing the cucumber party cannot be separated from our bodily engagements and interdependence with worlds. Touching-vision propels us to think speculatively with sensorial impressions and how our bodies can issue further action in our future engagements with these worlds. As Puig de la Bellacasa (2017) writes, "what we do in, to, a world can come back, reaffect someone somehow" (p. 115), and this is ethically compelling.

Watching for the first time the footage of the cucumber party filled me (Laura) with estrangement, struggle, and not-knowing. However, Ingrid enthusiastically reacted towards a section of the video that she described as "I am entering the sunbeams with my head". Ingrid enjoyed seeing her body moving towards the light projected by the sun, and the visual effect of some sunbeams passing across streams of her long hair while darkening the rest of the image. From my perspective, the fact that part of the visual field had blacked out was an undesirable disturbance in the flow of action. Ingrid's thoughts made me consider Marks' (2000) point about film and video-images as mimetically sensed in the body. This is, the possibility of thinking in video images not as a transmission of signs to be read but as a mimetic experience, where "video bears witness to an object and transfers the presence of that object to viewers" (p. xvii). Connecting with Deleuzian (1989) cinema-philosophy, Marks (2000) considers that in images, like the one of "entering the sunbeams with my head", the body is freed to its own gestures which at the same time frees perception from the expected flow of action. Hence, it forces us to think. The image brought Ingrid to an unexpected moment of contemplation, which rather than propelling an intellectual response, produced a body response that continued issuing and resurfacing over time. Time passed after the viewing, and one day Ingrid created a drawing, which featured us (Ingrid, Eric and I) with very tiny bodies and extra-long shadows with extensive legs. Ingrid noted the connection of 
this feature with the GoPro wide-lens and how she recalled our shadows being rendered. The video-mediated experience of being alongside the snails, affectively arose in Ingrid an interest for continuing the use of the chest-mounted GoPro in later neighbourhood walks, as well as a motivation for further activation, perception and thought around atmospheric and bodied interventions. This derivative activity attest to the incorporeality of the video-diagram as an abstract machine whose way of production operates in the indeterminate space between the visible and the articulable (Zdebik, 2013). What was done in/with the cucumber party came back, and continued re-affecting our bodies, life and movement in the neighbourhood (Puig de la Bellacasa, 2017).

Repeatedly watching the video, sometimes by myself, and sometimes with Ingrid, intensified my awareness of how in the activity of the cucumber party, Ingrid, Eric and I were not the only agents who saw, touched, acted. The video as a vision-touching technology deployed reality as an intra-acting more-than-human process of aliveness. The practices in, with and after the video were "entangled with the very matter of relating-being" (Puig de la Bellacasa, 2017, p. 114) and displaced the anthropocentric idea of the human as "master subject-agent that appropriates inanimate worlds" (p. 115). The video, as embedded in the series of mundane anecdotes with the snails, is generative of a view of care in parenting that does not depend of reproductive practices: making babies, successful school test performers, and eventual competitive workers within global capitalism. As Haraway's (2018) thinking seems to suggest, care-in-parenting it is an issue of composition or making kin not of reproduction. Making kin involves the building of situated patterns for learning to live and die with other-than-human others. Kin are not species, but assemblages made in daily and situated ways where parents, families, communities become more aware, learn, support, imagine, experiment with non-accumulative, non-extractive, non-individualizing ways of living as an ethics, aesthetics and politics of de-colonization and de-exploitation of parenting. 


\section{References}

Allen, G. (2001). Early intervention: The next steps. London: Cabinet Office.

Barad, K. (2007) .Meeting the universe halfway: Quantum physics and the entanglement of matter and meaning. Durham, NC, Duke University Press.

Braidoti, R. (2013). The posthuman. London: Polity Press.

Baraister, L. (2009). Maternal encounters: The ethics of interruption. New York, Routledge.

Burman E (2007). Deconstructing developmental psychology. London, Routledge.

Caton, L. \& Hackett, A. (2019). Head mounted, chest mounted, tripod or roaming?:

Ontological possibilities for doing visual research with children and GoPro cameras,. In N.J. Kucirkova, Rowsell \& G. Fallon (eds.) The Routledge international handbook of playing and learning with technology in early childhood. New York, Routledge.

Clarke, A. E. \& Haraway, D. (2018) (eds.). Making kin not population. Chicago, Prickly Paradigm Press.

Clarke, A. E. (2018). Introducing Making kin not population. In A. E. Clarke and D. Haraway (eds.) Making kin not population (pp. 1-41). Chicago, Prickly Paradigm Press.

Clarke, K. (2006). Childhood, parenting and early intervention: a critical examination of the Sure Start national programme. Critical Social Policy 26(4), pp. 699-721.

Deleuze, G. (1989 [1985]). Cinema 2: The time-image (trans. H. Tomlinson and R. Galeta). Minneapolis, MN: University of Minnesota Press. 
Department for Work and Pensions (DWP) (2017). Improving lives: Helping workless families, Available at: https://www.gov.uk/government/publications/improving-liveshelping-workless-families

Dermott, E. \& Pomati, M. (2016). 'Good' parenting practices: How important are poverty, education and time pressure? Sociology, 50(1), 125-142.

Elwick, S. (2015). 'Baby-cam' and researching with infants: Viewer, image and (not) knowing. Contemporary Issues in Early Childhood vol 16(4), 322-338.

Field, F. (2010). The foundation years: Preventing poor children becoming poor adults, London, Cabinet Office.

Foucault, M. (1984). What is Enlightenment? (trans. Porter C). In P. Rabinow (ed.), The Foucault Reader (pp. 32-50). New York: Pantheon.

Frost, S. (2016). Biocultural creatures: Towards a new theory of the human. Durham, NC, Duke University Press.

Grosz, E. (2011). Becoming undone: Darwinian reflections on life, politics and art. Durhan, NC, Duke University Press.

Hackett, A. (2017). Parents as researchers: Collaborative ethnography with parents. Qualitative Research, 17(5), 481-497.

Haraway, D. (1997).Modest_Witness@Second_Millenium.FemaleMan_Meets_OncoMouse: Feminism and technosience. New York, Routledge.

Haraway, D. (2003). The companion species manifesto: Dogs, people and significant otherness. Chicago, Prickly Paradigm Press. 
Haraway, D. (2016). Staying with the trouble. Making kin in the Chthulucene, Durham, NC, Duke University Press.

Haraway, D. (2018). Makin kin in the Chthulucene: reproducing multispecies justice. In A. E. Clarke \& D. Haraway (eds.), Making kin not population (pp. 67-100). Chicago, Prickly Paradigm Press.

Jensen, T. (2018). Parenting the crisis: the cultural politics of parent-blame. Bristol, U.K., Polity Press.

Kind, S. (2013). Lively entanglements: The doings, movements and enactments of photography, Global Studies of Childhood. 3(4), 427-441.

Latimer, J. (2013). Being alongside: rethinking relations amongst different kinds. Theory, Culture \& Society, 30(7/8), 77-104.

Marks, L. (2000). The skin of the film: Intercultural cinema, embodiment and the senses. Durham, NC, Duke University Press.

Marks, L. (2002). Touch: Sensous theory and multisensory media, Minneapolis, MN, Minnesota.

McRobbie, A. (2013). Feminism, the family and the new 'mediated' maternalism. New Formation, 80, 119-137.

Puig de la Bellacasa, M. (2017). Matters of care: Speculative ethics in more than human worlds. Minneapolis, MN, Minnesota.

Rose, J. (2018). Mothers: An essay on love and cruelty. London, Faber \& Faber. 
Rousell, D \& Cutter-Mackenzie, A (in press). 'The Parental Milieu: Biosocial connections with nonhuman animals, technologies, and the Earth', Journal of Environmental Education.

Trafí-Prats, L. (2018). Mothering as an aesthetics of existence. In C. M. Schulte, \& C. M. Thompson, (Eds.), Communities of practice: Art, play and aesthetics in early childhood (pp. 197-212). Cham, Switzerland, Springer.

Trafí-Prats, L. (2019). Thinking childhood art with care in an ecology of practices. In J. Osgood, \& M. Sakr, (Eds.), Postdevelopmental approaches to childhood art (pp. 177191). London, Bloomsbury.

Zdebik, J. (2013). Deleuze and the diagram: Aesthetic threads in visual organization. London, Bloomsbury. 
